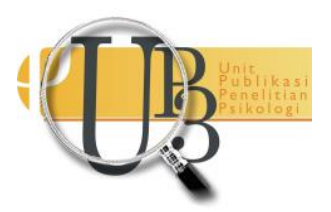

ARTIKEL PENELITIAN

\title{
Pengaruh Stres Kerja dan Coronavirus Anxiety terhadap Mental Well-Being pada Generasi Milenial
}

GISZKA GITA MASERATI \& HERISON PANDAPOTAN PURBA*

Departemen Psikologi Industri dan Organisasi, Fakultas Psikologi Universitas Airlangga

\begin{abstract}
ABSTRAK
Pandemi COVID-19 menyebabkan terjadinya perubahan pada berbagai aspek kehidupan. Tidak hanya mempengaruhi aspek kesehatan dan ekonomi bagi karyawan, tetapi juga berdampak pada psikologis mereka. Penelitian sebelumnya menyatakan bahwa pekerja medis dan masyarakat mengalami masalah psikologis akibat pandemi tersebut dalam bentuk rendahnya well-being. Penelitian ini bertujuan untuk mengetahui apakah terdapat pengaruh stres kerja dan coronavirus anxiety terhadap mental well-being pada generasi milenial. Sebanyak 313 karyawan generasi milenial yang sedang bekerja tetap maupun tidak tetap (kontrak) berpartisipasi dalam penelitian ini. Hasil penelitian ini menunjukkan adanya pengaruh negatif stres kerja dan coronavirus anxiety ketika diteliti secara simultan. Selain itu, secara parsial stres kerja dan coronavirus anxiety berpengaruh terhadap mental well-being dan coronavirus anxiety berpengaruh terhadap mental well-being. Hasil dari penelitian ini memiliki beberapa implikasi praktis, seperti dapat menjadi pertimbangan perusahaan untuk menyediakan program Employee Assistance Program yang dapat berperan efektif selama pandemi COVID-19.
\end{abstract}

Kata kunci: coronavirus anxiety, kesejahteraan, pandemi COVID-19, stres kerja

\begin{abstract}
The COVID-19 pandemic has caused changes in various aspects of life. It not only affects the health and economic aspects of employees, but also affects their psychology. Previous research has suggested that medical workers and the citizens are experiencing psychological problems due to the pandemic in the form of low well-being. The aim of this study is to determine the effect of job stress and coronavirus anxiety to mental well-being on millennial generation. A total of 313 millennial generation employees who are currently working permanently or not permanently (contract) participated in this study. The result showed that there is a simultan effect of job stress and coronavirus anxiety on mental well-being. In addition, job stress and coronavirus anxiety partially affect mental well-being. The results of this study have several practical implications, such as being a consideration for companies to provide an Employee Assistance Program that is effective during the COVID-19 pandemic.
\end{abstract}

Keywords: coronavirus anxiety, COVID-19 pandemic, job stress, well-being 
Naskah ini merupakan naskah dengan akses terbuka dibawah ketentuan the Creative Common Attribution License (CC-BY-4.0) (http://creativecommons.org/licenses/by/4.0), sehingga penggunaan, distribusi, reproduksi dalam media apapun atas artikel ini tidak dibatasi, selama sumber aslinya disitir dengan baik.

\section{PENDAHULUAN}

Tujuan yang ingin dicapai perusahaan tidak akan terlepas dari peran dan andil setiap karyawan sebagai penggerak kehidupan organisasi. Sudah selayaknya pemimpin perusahaan berperan untuk dapat memahami kondisi para karyawannya, mengingat dunia kerja saat ini telah terjadi pergeseran generasi antara generasi milenial dengan generasi sebelumnya. Adanya perbedaan sikap kerja yang dimiliki oleh generasi milenial dengan generasi sebelumnya juga perlu untuk menjadi salah satu fokus perusahaan dikarenakan sikap kerja yang dimiliki oleh karyawan, terutama dengan adanya pandemi COVID-19.

Pandemi COVID-19 merupakan wabah penyakit menular yang berasal dari Tiongkok sejak bulan Desember 2019. Pandemi COVID-19 sedang menjadi perhatian global karena telah menyebar ke ratusan negara di dunia dengan catatan jumlah kematian dan infeksi yang berselang ke negara-negara tersebut. Pandemi COVID-19 menyebabkan terjadinya perubahan pada berbagai aspek kehidupan. Tidak hanya mempengaruhi aspek kesehatan dan ekonomi bagi perusahaan dan karyawan, tetapi juga mempengaruhi sisi psikologis bagi mereka. Penelitian sebelumnya menyatakan bahwa pekerja medis dan masyarakat mengalami masalah psikologis akibat pandemi tersebut, seperti kegelisahan, depresi, dan stres karena peningkatan jumlah kasus dan kematian yang telah dikonfirmasi (G. Singh et al., 2020). Jumlah kasus yang dikonfirmasi memiliki dampak yang sangat besar pada fisik dan well-being individu (G. Singh et al., 2020). Sementara itu, Perkbox melaporkan bahwa 93\% karyawan Inggris telah menghadapi tantangan well-being pada tahun 2020 dan $60 \%$ pengusaha telah melihat well-being karyawan mereka lebih menderita sejak pandemi COVID-19 (Perkbox, 2018).

Dalam survei Global Human Capital Trends tahun 2020, 80\% responden mengidentifikasi well-being sebagai prioritas penting untuk kesuksesan organisasi mereka (Deloitte, 2020). Namun, sebuah penelitian di barat daya Inggris menemukan bukti penurunan kesejahteraan selama pandemi COVID-19 (Bu et al., 2020). Berdasarkan laporan dari Blue Cross Blue Shield Association, generasi milenial berada dalam kesehatan dan well-being yang lebih buruk daripada generasi sebelumnya (Ducharme, 2019). Hal itu ditunjang oleh data COVID-19: Mental Health and Well-Being surveillance report, dimana kelompok orang dewasa muda melaporkan kesehatan dan well-being yang lebih buruk selama pandemi daripada orang dewasa yang lebih tua (Kwong et al., 2020).

Kesejahteraan (well-being) merupakan konstruk yang luas sehingga diturunkan menjadi dua perspektif, yaitu pengalaman subjektif kebahagiaan dan kepuasan hidup (perspektif hedonic); serta positive psychological functioning, hubungan baik dengan orang lain, dan self-realization (perspektif eudaimonic) (Stewart-Brown \& Janmohamed, 2008). Menurut Mind (2020) kesejahteraan mental menggambarkan keadaan mental seseorang, bagaimana ia merasa, dan seberapa baik ia menghadapi kehidupan seharihari. Seseorang yang memiliki well-being yang baik akan relatif percaya diri dan memiliki self-esteem yang positif, dapat merasakan dan mengekspresikan berbagai emosi, dapat membangun dan memelihara hubungan baik dengan orang lain, merasa terlibat dengan dunia sekitar, bekerja dengan produktif, serta dapat mengatasi stres dalam kehidupan sehari-hari (Mind, 2020). Sementara sebaliknya apabila seseorang memiliki well-being yang rendah, maka mereka akan memiliki perasaan negatif dari hari ke hari dan tidak berfungsi secara baik (Mind, 2020). 
Kesejahteraan di tempat kerja didefinisikan sebagai perasaan dan tujuan psikologis yang dirasakan karyawan di lingkungan kerja (Cooper \& Robertson, 2011). Karyawan yang memiliki well-being yang baik berkaitan dengan berbagai organizational outcomes, seperti peningkatan kinerja, kepuasan kerja, keterlibatan kerja, peningkatan keuntungan, dan mengurangi pergantian karyawan (Russell, 2008). Oleh karena itu, kesejahteraan pada karyawan sangat penting guna menjaga karyawan agar dapat menjalankan perannya sesuai dengan target perusahaan. Selain itu, kesejahteraan dapat mempengaruhi karyawan dalam hal tingkah laku, pembuatan keputusan, dan interaksi dengan rekan kerja.

Berdasarkan beberapa hasil penelitian sebelumnya, terdapat faktor-faktor yang mempengaruhi wellbeing seseorang, diantaranya kepribadian (Ryan \& Deci, 2001), faktor demografis (Ryff, 1989), dukungan sosial (Ismail \& Shujaat, 2018), serta faktor kontekstual dan situasional (Hoorn, 2007). Desi, dkk (2017) melakukan penelitian mengenai hubungan antara faktor sosiodemografi (usia, jenis kelamin, status pernikahan, pendidikan, pekerjaan, dan pendapatan) dengan tingkat well-being di Ambon. Dalam penelitiannya, ia menemukan hasil bahwa faktor pekerjaan memiliki hubungan dengan afek positif dan negatif (subjective well-being) serta psychological well-being (Desi et al., 2017). Tempat kerja maupun pekerjaan memiliki dampak yang signifikan terhadap kesehatan dan kesejahteraan mental karyawan. Ketimpangan pada tuntutan pekerjaan dengan sumber daya yang ada (tekanan kerja), menyebabkan seseorang lebih banyak merasakan afek negatif dan ketidakpuasan hidup dalam bentuk rendahnya well-being. Karyawan harus mampu menghadapi segala macam tuntutan pekerjaan yang cukup berat, sehingga apabila karyawan tidak mampu menghadapi kondisi tersebut dapat menimbulkan dampak negatif seperti stres kerja.

Stres kerja merupakan kesadaran individu dan perasaan disfungsi akibat kondisi yang dirasakan di tempat kerja yang tersusun atas kecemasan dan tekanan waktu (Parker \& DeCotiis, 1983). Pandemi ini telah menekankan perlunya menanggapi krisis kesehatan mental karena telah mengganggu kehidupan kerja normal dan meningkatkan stres baik di rumah maupun di tempat kerja. Hal tersebut dibuktikan oleh survei dari UK Working Lives (2019) yang melaporkan bahwa satu dari empat pekerja menunjukkan kerja sebagai penyebab stres yang cukup besar dengan kondisi kerja yang intens dan penuh tekanan termasuk merasa lelah, sengsara, atau dibawah tekanan yang berlebihan (CIPD, 2020). Lebih lanjut, survei Attest di Inggris menunjukkan bahwa hampir 65\% orang yang berusia 18-40 tahun memiliki tingkat stres yang jauh lebih tinggi daripada rekan-rekan mereka yang lebih tua (Attest, 2020). Kemudian penelitian melalui Ginger menyatakan bahwa pekerja Amerika Serikat merasa stres kerja sebelum pandemi dengan hampir $60 \%$ orang dan naik mulai dari 48\% pada tahun 2019 (Glass, 2020).

Dalam konteks well-being, Issom \& Makbulah (2017) meneliti hal serupa yaitu mengetahui pengaruh stres situasi kerja terhadap psychological well-being. Pada penelitiannya, pengaruh yang dihasilkan bersifat negatif. Hal tersebut berarti semakin tinggi tingkat stres situasi kerja seseorang, maka tingkat psychological well-being akan semakin rendah (Issom \& Makbulah, 2017). Hal ini bertentangan dengan penelitian yang dilakukan oleh Siti Sarah (2018) yang tidak menemukan adanya pengaruh signifikan antara stres kerja dengan psychological well-being. Penelitian lain dilakukan oleh Setiasih (2012) mengenai pengaruh manfaat kerja, kepuasan kerja, dan stres kerja terhadap subjective well-being. Ia menemukan bahwa stres kerja memiliki pengaruh signifikan terhadap afek negatif, namun tidak signifikan terhadap aspek kepuasan hidup dan afek positif (Setiasih, 2012). Hasil penelitian itu sejalan dengan konsep subjective well-being yang terdiri dari faktor kognitif (kepuasan hidup) dan faktor afektif (afek positif dan afek negatif) (Diener \& Ryan, 2008).

Faktor lain yang mempengaruhi tingkat well-being seseorang adalah faktor kontekstual dan situasional. Faktor ini merupakan faktor individual yang dipengaruhi oleh konteks atau situasi tertentu (Hoorn, 2007). Situasi dunia saat ini, yaitu adanya pandemi COVID-19 dapat menjadi situasi yang mengancam 
dan berbahaya sehingga dapat menimbulkan munculnya kecemasan pada masyarakat. Pandemi COVID19 di hampir seluruh wilayah dunia berdampak pada semua aspek, termasuk kesehatan mental, terutama bagi mereka yang mengalami gangguan kecemasan. Kecemasan bermula dari kegelisahan masyarakat mengenai sesuatu yang tidak diketahui. Dalam menghadapi pandemi COVID-19, masyarakat saat ini diselimuti perasaan cemas karena ketidakpastian berapa lama pandemi akan berakhir.

Berdasarkan studi longitudinal dua generasi di Inggris, persentase tingkat kecemasan seseorang meningkat hampir naik dua kali lipat (24\%) selama pandemi COVID-19 dibandingkan dengan prapandemi (13\%) (Kwong et al., 2020). Sementara di Indonesia, survei Perhimpunan Sarjana dan Profesional Kesehatan Masyarakat Indonesia (Persakmi) bersama Ikatan Alumni Universitas Airlangga Komisariat Fakultas Kesehatan Masyarakat (IKA FKM UA) menemukan bahwa lebih dari 50\% responden mengalami kecemasan (PERSAKMI, 2020). Selanjutnya survei tersebut menemukan bahwa masyarakat yang berumur 30-39 tahun mengalami kecemasan terbanyak, sekitar 76\% dimana masyarakat tersebut termasuk dalam generasi milenial (PERSAKMI, 2020).

Berdasar pengertian Gao (2012) kecemasan dapat mengganggu fungsi kognitif dan emosi seseorang. Seseorang yang mengalami kecemasan bisa saja terjadi kekeliruan dalam menerjemahkan keadaankeadaan yang dihadapinya, bahkan melumpuhkan fungsi kognitifnya. Fungsi kognitif yang bermasalah tersebut dapat menyebabkan turunnya tingkat well-being seseorang. Hal tersebut didukung oleh penelitian sebelumnya dari Puji Safitri (2017) mengenai hubungan antara kecemasan dengan psychological well-being pada sarjana S1 dalam menghadapi dunia kerja di Pekanbaru. Hasil penelitiannya menunjukkan bahwa terdapat hubungan negatif signifikan antara kecemasan dengan psychological well-being (Safitri, 2017). Artinya, semakin tinggi kecemasan, maka tingkat psychological well-being akan semakin rendah. Penelitian serupa juga menemukan bahwa seseorang yang sudah memiliki psychological well-being yang baik, maka orang tersebut dapat mengontrol kecemasan mereka (Mutiarachmah \& Maryatmi, 2019).

Coronavirus anxiety adalah perasaan disfungsional yang terdiri dari pikiran-pikiran tidak menyenangkan, sensasi tidak menyenangkan, dan perubahan fisik yang terjadi dalam menanggapi pandemi virus corona (Lee, 2020). Penelitian mengenai kecemasan di masa pandemi COVID-19 dilakukan oleh Ahmed, dkk. Ahmed, dkk. (2020) meneliti tentang tingkat depresi, COVID-19 worry, dan coronavirus anxiety terhadap mental well-being di Bangladesh. Hasil penelitiannya menemukan bahwa terdapat hubungan negatif signifikan antara coronavirus anxiety dengan mental well-being. Artinya, semakin tinggi kecemasan akan virus corona pada seseorang maka tingkat mental well-being akan semakin rendah, dan sebaliknya. Kemudian penelitian lain yang dilakukan di Barat Daya Inggris juga menemukan bukti peningkatan awal kecemasan dan rendahnya well-being (Bu et al., 2020).

Perubahan kondisi saat pandemi COVID-19 dapat mempengaruhi psikologis generasi milenial sehingga menyebabkan stres kerja serta kecemasan bagi mereka. Stres dan kecemasan yang berhubungan dengan tempat kerja bukanlah fenomena baru. Banyak karyawan di AS melaporkan pekerjaan mereka sebagai sumber utama stres dan kecemasan yang jika dibiarkan dapat dengan mudah naik ke tingkat gangguan kecemasan dengan konsekuensi negatif bagi kesehatan fisik, kesejahteraan mental, produktivitas tempat kerja, dan peluang karir (S. Singh, 2020). Presiden American Psychiatric Association (APA), Dr. Bruce Scwartz pun menyatakan bahwa stres dan kecemasan yang disebabkan oleh pandemi dapat berdampak pada kesehatan fisik dan mental (well-being) seseorang (Preidt, 2020). Dalam penelitian ini, penulis mencoba menguji kembali seberapa besar pengaruh yang diberikan oleh stres kerja serta coronavirus anxiety terhadap tingkat mental well-being. Meskipun telah banyak literatur yang telah meneliti terkait hubungan well-being dengan stres kerja dan kecemasan, sebagian 
besar penelitian lebih berfokus pada salah satu aspek well-being, yaitu psychological well-being atau subjective well-being saja. Seperti penelitian dari Ulfah Hayati (2019) yang meneliti pengaruh stres kerja terhadap kesejahteraan subjektif yang dimediasi oleh resiliensi, kemudian penelitian dari Siti Sarah (2018) mengenai pengaruh stres kerja dan kepuasan kerja terhadap psychological well-being. Selain itu, penelitian-penelitian sebelumnya dilakukan pada populasi yang umum, tidak pada generasi tertentu. Oleh karena itu, urgensi penelitian ini berfokus untuk mengetahui pengaruh stres kerja dan coronavirus anxiety terhadap mental well-being pada generasi milenial.

Terdapat tiga hipotesis dalam penelitian ini, yaitu (1) terdapat pengaruh stres kerja dan coronavirus anxiety secara bersamaan terhadap mental well-being pada generasi milenial; (2) terdapat pengaruh stres kerja terhadap mental well-being pada generasi milenial; dan (3) terdapat pengaruh coronavirus anxiety terhadap mental well-being pada generasi milenial.

\section{Desain Penelitian}

\section{METODE}

Penelitian ini menggunakan pendekatan kuantitatif-eksplanatori dengan desain cross-sectional. Penelitian kuantitatif-eksplanatori dapat digunakan untuk mengukur atau menguji hubungan sebabakibat dari dua atau lebih variabel. Teknik pengumpulan data pada penelitian ini menggunakan metode survei dengan alat ukur berupa kuesioner.

\section{Partisipan}

Partisipan dalam penelitian ini adalah generasi milenial, yaitu yang lahir pada tahun 1980-2000 (berusia 20 hingga 40 tahun) dan saat ini sedang bekerja, baik tetap maupun tidak tetap. Teknik sampling yang digunakan dalam penelitian ini adalah nonprobability sampling dengan teknik accidental sampling. Jumlah sampel partisipan dalam penelitian ini diambil dan dipilih berdasarkan penghitungan menggunakan aplikasi $G^{*}$ Power 3.1. Pengambilan data diawali dengan informed consent yang menyatakan partisipan bersedia berpartisipasi dalam penelitian ini.

Partisipan yang didapat dalam penelitian ini berjumlah 313 orang $\left(M_{\text {usia }}=26,2 ; S D_{\text {usia }}=5,11 ; 70,3 \%\right.$ perempuan). Sebagian besar partisipan memiliki latar belakang pendidikan akhir S1 (58,78\%) dan status perkawinan tidak menikah, yaitu sebesar 69\%. Apabila ditinjau dari segi karir, sebagian besar partisipan baru memulai karirnya dengan masa kerja kurang dari lima tahun $(87,85 \%)$ dan posisi jabatannya pun masih didominasi oleh low management $(62,61 \%)$ kemudian diikuti oleh middle management $(33,22 \%)$. Partisipan dalam penelitian ini memiliki status pekerjaan yang hampir merata, yaitu bekerja tetap $(47,92 \%)$ dan bekerja tidak tetap/kontrak $(52,08 \%)$.

\section{Pengukuran}

Terdapat dua variabel independen dan satu variabel dependen dalam penelitian ini. Variabel independen yang digunakan yaitu stres kerja dan coronavirus anxiety, sementara variabel dependen yang digunakan yaitu mental well-being. Pengukuran penelitian ini terdiri dari tiga instrumen, antara lain yang pertama The Warwick-Edinburgh Mental Well-Being Scale (WEMWBS) yang diadaptasi dari (Stewart-Brown \& Janmohamed, 2008) untuk mengukur mental well-being. Instrumen kedua, yaitu Job Stress Scale (JSS) yang diadopsi dari (Ramadhana, 2016) untuk mengukur stres kerja yang terdiri atas dimensi kecemasan dan tekanan waktu. Instrumen terakhir yaitu Coronavirus Anxiety Scale (CAS) yang diadaptasi dari (Lee, 2020) untuk mengukur kecemasan selama pandemi COVID-19. 
Ketiga alat ukur menggunakan skala Likert dimana semakin tinggi skor yang didapat menunjukkan dukungan yang lebih besar terhadap variabel. Skala WEMWBS terdiri dari 14 aitem dengan 5 pilihan jawaban (1="tidak pernah", 5="selalu"), dengan koefisien reliabilitas 0.917. Skala JSS terdiri dari 13 aitem dengan 4 pilihan jawaban (1="sangat tidak setuju", 4="sangat setuju"), dengan koefisien reliabilitas 0.768 (kecemasan) dan 0.791 (tekanan waktu). Sementara skala CAS terdiri dari 5 aitem dengan 5 pilihan jawaban (1="tidak sama sekali", 5="hampir setiap hari") dengan koefisien reliabilitas 0.793 .

\section{Analisis Data}

Teknik analisis yang digunakan dalam penelitian ini adalah analisis regresi linear berganda. Uji regresi linear berganda digunakan untuk mengetahui pengaruh kedua variabel independen terhadap satu variabel dependen. Sebelum melakukan uji regresi, penulis melakukan uji asumsi terlebih dahulu yang terdiri dari uji normalitas, uji linearitas, uji heterokedastisitas, uji multikolinearitas, dan uji korelasi. Penulis menggunakan aplikasi IBM SPSS Statistic 22 for Windows.

\section{HASIL PENELITIAN}

\section{Analisis Deskriptif}

Penulis melakukan analisis deskriptif untuk mendeskripsikan atau menggambarkan statistik data yang telah terkumpul. Variabel mental well-being memiliki nilai mean sebesar 3,70 ( $\mathrm{SD}=0,645$; Min=1,43; Max=5), yang artinya rata-rata partisipan merasa cukup sejahtera atau memiliki tingkat well-being yang sedang. Kemudian variabel stres kerja memiliki mean sebesar 2,33 ( $\mathrm{SD}=0,476$; $\mathrm{Min}=1,08$; $\mathrm{Max}=3,77)$ yang artinya rata-rata kecenderungan partisipan memiliki tingkat stres kerja yang sedang. Sementara variabel coronavirus anxiety memiliki mean sebesar 0,35 (SD=0,475; Min=0; Max=2,6), yang artinya rata-rata partisipan memiliki tingkat kecemasan akan virus corona yang rendah.

\section{Analisis Regresi}

Pada penelitian ini penulis menggunakan analisis regresi berganda untuk melihat pengaruh stres kerja dan coronavirus anxiety sekaligus terhadap mental well-being. Berdasarkan model summary dan model ANOVA, dapat diketahui bahwa kedua variabel independen memiliki pengaruh secara bersama-sama (simultan) terhadap mental well-being $\left(F(2,310)=16,001 ; p=0,000 ; R^{2}=0,094\right)$ serta varians dari stres kerja dan coronavirus anxiety dapat menjelaskan 9,4 persen dari varians mental well-being. Maka dapat disimpulkan bahwa stres kerja dan coronavirus anxiety secara simultan memiliki pengaruh yang signifikan terhadap mental well-being,

Pada model koefisien regresi berganda, dapat diketahui stres kerja $(B=-0,254 ; S E=0,076 ; t=-3,331$; $p=0,001)$ berkorelasi negatif dalam menjelaskan mental well-being. Kemudian coronavirus anxiety $(B=-$ 0,$265 ; S E=0,076 ; t=-3,473 ; p=0,001$ ) juga berkorelasi negatif dalam menjelaskan mental well-being. Maka dapat disimpulkan bahwa stres kerja maupun coronavirus anxiety secara parsial berpengaruh negatif terhadap mental well-being.

Penulis melakukan analisis tambahan untuk mengetahui pengaruh masing-masing dimensi variabel stres kerja terhadap mental well-being. Dapat diketahui dimensi tekanan waktu $(B=0,006 ; S E=0,013$; $t=0,493 ; p=0,622)$ berkorelasi positif dalam menjelaskan mental well-being. Sementara dimensi kecemasan $(B=-0,073 ; S E=0,018 ; t=-4,043 ; p=0,000)$ berkorelasi negatif dalam menjelaskan mental

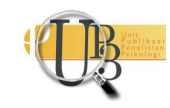


well-being. Oleh karena itu, dapat dikatakan bahwa hanya dimensi kecemasan yang berpengaruh secara signifikan terhadap mental well-being karena memiliki nilai signifikansi kurang dari 0,05, sementara dimensi tekanan waktu tidak berpengaruh secara signifikan karena memiliki nilai signifikansi sebesar 0,622 .

\section{DISKUSI}

Penelitian ini bertujuan untuk mengetahui apakah terdapat pengaruh stres kerja dan coronavirus anxiety terhadap mental well-being pada generasi milenial. Berdasarkan serangkaian analisis yang telah dilakukan, ditemukan hasil bahwa kedua variabel independen ketika diteliti secara terpisah maupun secara simultan memiliki pengaruh terhadap mental well-being dengan sifat yang sama, yaitu negatif. Hal ini dibuktikan dengan nilai signifikansi sebesar 0,000. Angka ini lebih kecil dari derajat minimal signifikansi yakni sebesar 0,05 . Sehingga dapat disimpulkan bahwa stres kerja dan coronavirus anxiety secara bersamaan memiliki pengaruh yang signifikan terhadap mental well-being. Hal itu sejalan dengan pernyataan Presiden American Psychiatric Association (APA), Dr. Bruce Scwartz yang menyatakan bahwa stres dan kecemasan yang disebabkan oleh pandemi dapat berdampak pada kesehatan fisik dan mental (well-being) seseorang (Preidt, 2020). Kemudian diperkuat oleh survei UK Health \& Wellbeing, yang menemukan bahwa generasi milenial dan generasi $\mathrm{Z}$ lebih merasakan tekanan hidup dengan melaporkan tingkat stres kerja dan kecemasan yang lebih tinggi dibandingkan dengan generasi sebelumnya (Attest, 2020).

Pada hasil di atas dapat dilihat pula nilai R square sebesar 0,094. Dari angka tersebut dapat dikatakan bahwa kedua variabel independen mampu menyumbang sebesar 9,4\% terhadap mental well-being. Kontribusi tersebut dapat dikatakan tidak terlalu besar meskipun tetap memberikan pengaruh yang signifikan. Menurut Annastasia, psikolog dan dosen Fakultas Universitas Diponegoro itu menyatakan bahwa masyarakat di masa pandemi akan menghadapi tiga tahapan Learning Zone Model berdasar teori Senninger (2000), yaitu panic zone, learning zone, dan comfort zone (Perkasa, 2020). Pada masa awal pandemi, masyarakat dikejutkan dengan berbagai perubahan di setiap aspek kehidupan sehingga hal itu dikategorikan ke dalam panic zone. Sementara learning zone adalah zona di mana seseorang belajar hal baru untuk beradaptasi, seperti menemukan ritme bekerja dari rumah meskipun terkadang mengalami kesulitan untuk berkomunikasi (Perkasa, 2020). Selain itu dengan mengikuti protokol kesehatan yang telah ditetapkan, seperti menggunakan masker, mencuci tangan, dan menerapkan physical distancing. Oleh karena itu, hal tersebut dapat diasumsikan sebagai salah satu penyebab rendahnya kontribusi stres dan kecemasan terhadap mental well-being.

Sedangkan untuk uji parsial pada variabel independen pertama, peneliti memperoleh hasil bahwa stres kerja mempunyai pengaruh negatif secara signifikan terhadap mental well-being. Artinya semakin tinggi stres kerja yang dialami oleh karyawan generasi milenial, maka tingkat well-being akan semakin rendah. Hal yang serupa dinyatakan oleh Zarbova dan Karabeliova bahwa stres dan well-being saling berhubungan negatif signifikan (Zarbova \& Karabeliova, 2018). Penelitian lain menyatakan bahwa tingkat well-being seseorang lebih tinggi ketika ia sedang mengalami sedikit stres daripada merasakan lebih banyak stres (Krejtz et al., 2016). Penelitian yang dilakukan oleh Anggraeni dan Miftakhul Jannah (2014) juga menunjukkan bahwa terdapat hubungan antara psychological well-being dengan stres kerja. Sementara itu, subjective well-being juga berhubungan secara signifikan dengan stres kerja (Saputra, 2011). Dalam penelitian Goldstein (2007), well-being dan stres saling berhubungan secara signifikan, yang berarti meningkatkan well-being dapat mengurangi stres seseorang.

Hasil penelitian ini tidak sejalan dengan penelitian sebelumnya yang meneliti pengaruh stres kerja dan kepuasan kerja terhadap psychological well-being pada polisi wanita (Sarah, 2018). Penelitian dari Siti 
Sarah tersebut menunjukkan bahwa variabel stres kerja, baik dimensi tekanan waktu maupun kecemasan tidak memiliki pengaruh yang signifikan terhadap psychological well-being. Hal tersebut dapat diasumsikan karena adanya perbedaan karakteristik subjek penelitian. Subjek penelitian dari Siti Sarah (2018) merupakan polisi wanita yang didominasi oleh generasi X, sementara subjek penelitian ini merupakan generasi milenial. Dalam penelitian ini, stres kerja pada generasi milenial dinilai menghambat sehingga berpengaruh pada well-being mereka, hal itu diperparah dengan adanya pandemi COVID-19. Pandemi COVID-19 merupakan sebuah tantangan bagi karyawan generasi milenial terkait dengan stres di tempat kerja. Generasi milenial merasakan lebih banyak stres karena adanya tekanan dan tuntutan, isolasi sosial berkepanjangan karena sistem work from home, serta kemungkinan PHK (S. Singh, 2020).

Secara konstruk, stres kerja adalah kondisi yang muncul dari interaksi antar manusia dan pekerjaan yang dikarakteristikan oleh perubahan yang memaksa mereka untuk menyimpang dari fungsi normal (Beehr \& Newman, 1978). Stres memiliki hubungan yang lebih kuat terhadap respon emosi negatif daripada respon emosi positif, sehingga karyawan dapat dikatakan tidak memiliki perasaan positif yang ditunjukkan dengan rendahnya well-being. Stres kerja dapat dialami oleh seseorang apabila kemampuannya tidak memadai untuk menghadapi atau menyesuaikan diri, sebagai akibat dari aksi lingkungan, situasi atau peristiwa yang menyebabkan tuntutan fisik dan atau psikologi secara berlebihan terhadap seseorang (Lindawati, 2013). Ketimpangan pada tuntutan pekerjaan dengan sumber daya yang ada (tekanan kerja), menyebabkan seseorang lebih banyak merasakan afek negatif dan ketidakpuasan hidup dalam bentuk rendahnya well-being.

Di sisi lain, tampaknya karyawan telah memiliki cara agar dapat bertahan di masa pandemi sehingga akan memunculkan perilaku dan kebiasaan baru. Karyawan yang bekerja pada masa pandemi dipaksa untuk beradaptasi, contohnya melalui rapat, pelatihan, atau pertemuan secara online. Dalam menghadapi pandemi COVID-19, karyawan sudah sepatutnya berusaha untuk menemukan solusi agar kepentingan pribadi dan organisasi dapat berjalan beriringan. Karyawan memiliki kesadaran diri dan rasa tanggung jawab untuk menjaga kesehatan yang menjadi hal penting agar dapat tetap bekerja secara optimal di tengah masa pandemi. Hal tersebut dapat ditunjukkan melalui skor rata-rata karyawan dalam penelitian ini, yaitu sebesar 2,33 yang tergolong memiliki tingkat stres sedang. Hal itu dapat diasumsikan karyawan mulai menemukan cara mengelola stres yang dihadapi dengan menjaga keseimbangan antara kesehatan fisik dan kesehatan mental mereka.

Selanjutnya penulis melakukan analisis tambahan pada dimensi-dimensi stres kerja. Variabel stres kerja memiliki dua dimensi, yaitu tekanan waktu dan kecemasan. Dimensi dari variabel stres kerja yang pertama adalah tekanan waktu. Dalam penelitian ini, dimensi tekanan waktu tidak memberikan pengaruh yang signifikan terhadap mental well-being. Temuan ini serupa dengan penelitian dari Siti Sarah (2018) yang menemukan bahwa dimensi tekanan waktu tidak memiliki pengaruh signifikan terhadap psychological well-being. Tekanan waktu merupakan persepsi karyawan ketika ia merasa tidak mampu menyelesaikan pekerjaannya sesuai dengan waktu yang telah ditentukan. Sementara dimensi kedua, yaitu kecemasan memberikan pengaruh signifikan terhadap mental well-being. Kecemasan diartikan dengan adanya kegelisahan yang dialami oleh karyawan yang berkaitan dengan pekerjaan. Dimensi tekanan waktu dipersepsikan positif dengan mental well-being. Hal tersebut dapat diasumsikan bahwa generasi milenial dengan tuntutan waktu yang diberikan justru membuat mereka merasa terpacu dan memiliki potensi untuk dapat berkontribusi lebih terhadap organisasi, sehingga dapat meningkatkan well-being mereka. Sementara aspek negatif dalam stres kerja dijelaskan pada dimensi kecemasan terhadap mental well-being. Tuntutan pekerjaan, tanggung jawab, serta konsekuensi ketika bekerja selama pandemi membuat generasi milenial merasa tertekan dan memiliki kecemasan yang 
berkontribusi lebih besar pada stres kerja sehingga hal tersebut dapat berdampak pada well-being karyawan.

Beralih ke variabel independen kedua yaitu coronavirus anxiety, hasil yang ditemukan adalah terdapat pengaruh negatif yang ditimbulkan dari coronavirus anxiety terhadap mental well-being. Artinya, ketika tingkat coronavirus anxiety karyawan generasi milenial tinggi, maka tingkat mental well-being cenderung rendah. Hal tersebut sejalan dengan penelitian dari Ahmed, dkk. (2020) yang meneliti tingkat depresi, COVID-19 worry, dan coronavirus anxiety terhadap mental well-being dan menemukan bahwa terdapat hubungan negatif signifikan antara coronavirus anxiety dengan mental well-being (Ahmed et al., 2020). Penelitian dari Puji Safitri (2017) juga menunjukkan adanya hubungan negatif signifikan antara kecemasan dengan psychological well-being. Kemudian penelitian yang dilakukan di Barat Daya Inggris juga menemukan adanya peningkatan kecemasan yang menyebabkan rendahnya well-being saat pandemi COVID-19 (Bu et al., 2020).

Segala bentuk keadaan yang dapat mengancam kesejahteraan seseorang dapat menyebabkan kecemasan, seperti adanya pandemi COVID-19. Pandemi COVID-19 telah menjadi penekan, terutama karena ini adalah infeksi virus baru yang belum memiliki vaksin dan hanya dapat diobati secara simtomatik (Xiao et al., 2020). Saat ini masyarakat telah merepresentasikan perilaku terkait kecemasan yang menunjukkan bahwa virus corona tidak hanya beresiko pada kesehatan fisik, tetapi juga sangat membebani kesehatan mental seseorang. Berdasar pengertian Gao (2012) kecemasan dapat mengganggu fungsi kognitif dan emosi seseorang. Seseorang yang mengalami kecemasan bisa saja terjadi kekeliruan dalam menerjemahkan keadaan-keadaan yang dihadapinya, bahkan melumpuhkan fungsi kognitifnya (Gao et al., 2012). Fungsi kognitif yang bermasalah tersebut dapat menyebabkan turunnya tingkat well-being seseorang.

Hasil penelitian pengaruh dari coronavirus anxiety terhadap mental well-being memang signifikan, namun pada penelitian ini sebagian besar karyawan generasi milenial memiliki tingkat kecemasan rendah yang ditunjukkan dengan nilai rata-rata sebesar 0,35. Setelah merasakan dampak pandemi COVID-19, tampaknya masyarakat telah menemukan cara untuk menurunkan kecemasan, salah satunya adalah patuh pada protokol kesehatan yang telah ditetapkan. Hal tersebut sejalan dengan analisis Lingkaran Survei Indonesia (LSI) Denny JA dengan data sekunder dari beberapa penelitian sebelumnya, yaitu peningkatan penerapan protokol kesehatan, seperti memakai masker, menjaga jarak, dan mencuci tangan (3M) untuk mengurangi penyebaran virus dianggap berdampak pada persepsi masyarakat (Hidayatullah, 2020). Kemudian, melihat keberhasilan negara lain dalam mengendalikan virus melalui berita menyebabkan kecemasan masyarakat akan virus corona menurun.

Penelitian yang dilakukan pada populasi Inggris juga menunjukkan penurunan sedang dalam kecemasan pada bulan Mei 2020 (Gallagher \& Wetherell, 2020), kemudian berdasarkan studi sosial COVID-19 terhadap 90.000 orang dewasa Inggris yang memantau kesehatan mental selama lockdown menunjukkan bahwa tingkat kecemasan dan depresi turun ketika kebijakan lockdown dicabut (Bu et al., 2020). Kesehatan mental dan well-being seseorang tampaknya telah terpengaruh pada fase awal pandemi COVID-19. Hal itu menunjukkan bahwa tingkat kecemasan tertinggi berada pada tahap awal lockdown, tetapi menurun ketika seseorang beradaptasi dengan keadaan (Bu et al., 2020). Selain itu, berdasarkan analisis LSI Denny JA, telah terjadi pergeseran kecemasan masyarakat Indonesia terhadap virus corona. Adanya penurunan ekonomi serta melihat jumlah masyarakat yang kesusahan ekonomi jauh lebih banyak daripada masyarakat yang terpapar COVID-19 menyebabkan kecemasan akan virus corona menurun dan bergeser menjadi kecemasan akan keadaan ekonomi masyarakat Indonesia itu sendiri (Hidayatullah, 2020). Oleh karena itu, rendahnya pengaruh kecemasan terhadap mental wellbeing dapat diasumsikan karena karyawan telah beradaptasi dengan keadaan serta terjadi pergeseran

Buletin Riset Psikologi dan Kesehatan Mental (BRPKM) 2021, Vol. 1(1), 183-195 
kecemasan ke kondisi ekonomi mereka.

\section{SIMPULAN}

Berdasarkan temuan penelitian, maka dapat ditarik kesimpulan bahwa terdapat pengaruh stres kerja dan coronavirus anxiety secara simultan terhadap mental well-being pada generasi milenial. Hasil tersebut menyatakan bahwa $\mathrm{H}_{1}$ dalam penelitian ini diterima. Kemudian, dalam penelitian ini juga didapatkan hasil bahwa terdapat pengaruh stres kerja maupun coronavirus anxiety secara parsial terhadap mental well-being pada generasi milenial. Hasil tersebut berarti bahwa $\mathrm{H}_{2}$ dan $\mathrm{H}_{3}$ dalam penelitian ini diterima.

Saran yang dapat diberikan bagi penelitian selanjutnya adalah dengan menambahkan variabel moderator di antara hubungan stres kerja dan well-being, seperti variabel dukungan sosial (Yang et al., 2019). Kemudian peneliti selanjutnya dapat memastikan persebaran sampel pada tiap variabel demografis, menentukan faktor penyebab kecemasan dan dampak psikologis karyawan selama atau setelah pandemi COVID-19 dengan menggunakan desain longitudinal, serta menggunakan alat ukur yang lebih menyesuaikan dengan konteks dan fenomena yang ada di Indonesia. Sementara itu, saran yang dapat diberikan untuk karyawan yaitu dapat memperbanyak support group. Lalu, karyawan diharapkan berkonsultasi dengan konselor di bagian SDM perusahaan atau psikolog apabila memiliki keluhan stres, kecemasan, maupun kesejahteraan mental yang berkelanjutan.

Hasil dalam penelitian ini dapat menjadi pertimbangan bagi perusahaan untuk menyediakan program Employee Assistance Program (EAP). Program tersebut dapat berperan efektif mengingat pandemi COVID-19 memberi dampak pada karyawan pada berbagai sektor, tidak hanya dari tempat kerja. Selain itu, untuk menanggulangi stres kerja pada karyawan, perusahaan disarankan untuk membuat program pengembangan karyawan secara virtual, seperti pelatihan manajemen stres.

\section{UCAPAN TERIMAKASIH}

Penulis berterimakasih kepada ibu dan orang-orang terdekat penulis yang telah memberikan dukungan sehingga penelitian ini dapat terselesaikan dengan baik.

\section{DEKLARASI POTENSI TERJADINYA KONFLIK KEPENTINGAN}

Giszka Gita Maserati dan Herison Pandapotan Purba tidak bekerja, menjadi konsultan, memiliki saham, atau menerima dana dari perusahaan atau organisasi manapun yang mungkin akan mengambil untung dari diterbitkannya naskah ini."

\section{PUSTAKA ACUAN}

Ahmed, O., Faisal, R. A., Sharker, T., Lee, S. A., \& Jobe, M. C. (2020). Adaptation of the bangla version of the covid-19 anxiety scale. International Journal of Mental Health and Addiction. https://doi.org/10.1007/s11469-020-00357-2

Attest. (2020). UK Health Report 2020.

Beehr, T. A., \& Newman, J. E. (1978). Job stress, employee health, and organizational effectiveness: a facet analysis, model, and literature review. Personnel Psychology, 31(4), 665-699.

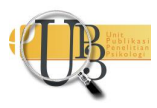


https://doi.org/10.1111/j.1744-6570.1978.tb02118.x

Bu, F., Steptoe, A., \& Fancourt, D. (2020). Loneliness during strict lockdown: trajectories and predictors during the COVID-19 pandemic in 38,217 adults in the UK. 1-19. https://doi.org/10.1101/2020.05.29.20116657

CIPD. (2020). Health and well-being at work: Survey Report.

Cooper, C., \& Robertson, I. (2011). Well-being-Productivity and Happiness at Work. London: Palgrave MacMillan.

Deloitte. (2020). The social enterprise at work : Paradox as a path forward. 2020 Deloitte Global Human Capital Trends. Deloitte Insights.

Desi, Tomasoa, S. J., \& Soegijono, S. P. (2017). Well-being: studi sosiodemografi di ambon. Jurnal Keperawatan Muhammadiyah, 2(2). https://doi.org/10.30651/jkm.v2i2.947

Diener, E., \& Ryan, K. (2008). Subjective well-being : a general overview. 39(4), 391-406.

Ducharme, J. (2019). Millennials Love Wellness. But They're Not as Healthy as People Think, Report Says I Time. Diakses melalui https://time.com/5577325/millennials-less-healthy/

Gallagher, S., \& Wetherell, M. (2020). Risk of depression in family caregivers: unintended consequence of covid-19. BJPsych Open. https://doi.org/10.1101/2020.06.15.20131532

Gao, Y. Q., Pan, B. C., Sun, W., Wu, H., Wang, J. N., \& Wang, L. (2012). Anxiety symptoms among Chinese nurses and the associated factors: a cross sectional study. BMC Psychiatry, 12. https://doi.org/10.1186/1471-244X-12-141

Glass, R. (2020). Coronavirus is stressing 7 of 10 U.S. workers to the max, and companies need to help them now. Diakses melalui MarketWatch: https://www.marketwatch.com/story/coronavirus-isstressing-7-of-10-us-workers-to-the-max-and-companies-need-to-help-them-now-2020-04-09

Hidayatullah, T. (2020). Pengentasan virus harus tetap maksimal, meski warga makin resah atas kondisi ekonomi. Diakses melalui https://lokadata.id/artikel/pengentasan-virus-harus-tetap-maksimalmeski-warga-makin-resah-atas-kondisi-ekonomi

Hoorn, A. (2007). A Short Introduction To Subjective Well-Being: Its Measurement, Correlates and Policy Uses. International Studies, 2-3.

Ismail, Z., \& Shujaat, N. (2018). Factors Affecting the Mental Well-Being of Undergraduate Students in Karachi. Advances in Social Sciences Research Journal, 5(3), 508-519. https://doi.org/10.14738/assrj.53.3704

Issom, F. L., \& Makbulah, R. (2017). Pengaruh Stres Situasi Kerja Terhadap Psychological Well-Being Pada Guru Honorer Madrasah Ibtidaiyah Di Kota Tangerang. Perspektif Ilmu Pendidikan, 31(1), 6167.

Krejtz, I., Nezlek, J. B., Michnicka, A., Holas, P., \& Rusanowska, M. (2016). Counting One’s Blessings Can Reduce the Impact of Daily Stress. Journal of Happiness Studies, 17(1), 25-39. https://doi.org/10.1007/s10902-014-9578-4

Kwong, A. S., Pearson, R. M., Adams, M. J., Northstone, K., Tilling, K., Smith, D., Fawns-Ritchie, C., Bould, H., Warne, N., Zammit, S., Gunnell, D., Moran, P., Micali, N., Reichenberg, A., Hickman, M., Rai, D., Haworth, S., Campbell, A., Altschul, D., ... Timpson, N. J. (2020). Mental health during the COVID-19 pandemic in two longitudinal UK population cohorts. medRxiv, 1-27. 
https://doi.org/https://doi.org/10.1101/2020.06.16.20133116

Lee, S. A. (2020). Coronavirus Anxiety Scale: A brief mental health screener for COVID-19 related anxiety. Death Studies, 44(7), 393-401. https://doi.org/10.1080/07481187.2020.1748481

Lindawati, R. (2013). Work Stress (Stres Kerja).

Mind. (2020). The mental health emergency: How has the coronavirus pandemic impacted our mental health?

Mutiarachmah, D., \& Maryatmi, A. S. (2019). Hubungan antara regulasi diri dan psychological well-being dengan kecemasan dalam menghadapi dunia kerja pada mahasiswa tingkat akhir jurusan kesejahteraan sosial uin syarif hidayatullah jakarta. Jurnal IKRA-ITH Humaniora, 3(3), 163-177.

Parker, D. E., \& DeCotiis, T. A. (1983). Organizational Determinants of Job Stress. Organizational Behavior and Human Performance, 32, 160-177.

Perkasa, G. (2020). Bagaimana Keluar dari Kecemasan dan Rasa Takut di Masa Pandemi? Diakses melalui https://lifestyle.kompas.com/read/2020/06/03/223724720/bagaimana-keluar-dari-

kecemasan-dan-rasa-takut-di-masa-pandemi?page=all

Perkbox. (2018). The 2018 UK Workplace Stress Survey.

PERSAKMI. (2020). Mayoritas Masyarakat Indonesia Alami Kecemasan di Masa Pandemi Covid-19 • Persakmi (Perhimpunan Sarjana dan Profesional Kesehatan Masyarakat Indonesia). Diakses melalui http://persakmi.or.id/headlines/mayoritas-masyarakat-indonesia-alami-kecemasan-di-masapandemi-covid-19/

Preidt, R. (2020). Poll Finds High Anxiety in the Time of Coronavirus / Health News / US News. Diakses melalui https://www.usnews.com/news/health-news/articles/2020-03-25/poll-finds-highanxiety-in-the-time-of-coronavirus

Ramadhana, T. (2016). Konflik Peran Ganda Dan Stres Kerja Pada Karyawan Wanita Bank Bumn Di Banda Aceh. https://etd.unsyiah.ac.id/baca/index.php?id=26296\&page=1

Russell, J. E. A. (2008). Promoting subjective well-being at work. Journal of Career Assessment, 16(1), 117-131. https://doi.org/10.1177/1069072707308142

Ryan, R. M., \& Deci, E. L. (2001). On happiness and human potentials: A review of research on hedonic and eudaimonic well-being. Annual Review of Psychology, 52, 141-166. https://doi.org/10.1146/annurev.psych.52.1.141

Ryff, C. D. (1989). Happiness is everything, or is it? Explorations on the meaning of psychological wellbeing. Journal of Personality and Social Psychology, 57(6), 1069-1081. https://doi.org/10.1037/0022-3514.57.6.1069

Safitri, P. (2017). Hubungan kecemasan dengan psychological well-being sarjana s1 dalam menghadapi dunia kerja.

Saputra, Y. (2011). Hubungan antara stres kerja dengan kesejahteraan subjektif pada karyawan perusahaan leasing di lembaga keuangan.

Sarah, S. (2018). Pengaruh stres kerja dan kepuasan kerja terhadap psychological well-being pada polisi wanita.

Setiasih. (2012). Pengaruh manfaat kerja, kepuasan kerja dan stres kerja terhadap subjective wellbeing.

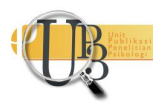


Singh, G., Singh, A., Zaidi, S. Z. H., \& Sharma, S. (2020). A study on mental health and well-being of individuals amid covid-19 pandemic lockdown. IX(V), 952-963.

Singh, S. (2020). Workplace Stress and Anxiety After COVID-19. Diakses melalui business.com: https://www.business.com/articles/workplace-stress-anxiety-covid-19/

Stewart-Brown, S., \& Janmohamed, K. (2008). Warwick-Edinburgh Mental Well-being Scale (WEMWBS) User Guide. Warwick Medical School, University of Warwick.

Xiao, H., Zhang, Y., Kong, D., Li, S., \& Yang, N. (2020). The effects of social support on sleep quality of medical staff treating patients with coronavirus disease 2019(COVID-19) in January and February 2020 in China. Medical Science Monitor, 26, 1-8. https://doi.org/10.12659/MSM.923549Zarbova, B., \& Karabeliova, S. (2018). Stress and Well-Being. 